\title{
Tunnel access for ridge augmentation: A review
}

\author{
Giuseppe D’Albis ${ }^{1}$, Vincenzo D’Albis ${ }^{2}$, Jonhson Cesário de Oliveira Júnior ${ }^{3}$, Fabrizio D'Orazio ${ }^{4}$ \\ ${ }^{1}$ Department of Medical Biotechnology, University of Siena, Siena, ${ }^{2}$ Private Practice, Mola di Bari (BA), Italy, ${ }^{3}$ ABO - Seção \\ Paraíba, João Pessoa - PB, Brazil, ${ }^{4}$ Private practice, Turin, Italy
}

\begin{abstract}
In traditional bone regeneration, the periosteal layer of the flap must be released to achieve tension-free primary wound closure. Several minimally invasive tunnel techniques have been introduced to augment the bone volume for prosthetic-driven implant placement, thus minimizing tissue trauma and patient morbidity. This literature review aimed at analyzing the available literature on ridge augmentation with a lateral tunnel access approach, and detailed the surgical protocols, materials, advantages, indications for use, disadvantages, and complications. The Medline and PubMed medical databases were searched for reports published between 2005 and March of 2021. Seventeen articles describing minimally invasive tunnel techniques for ridge augmentation were identified. Preservation of the integrity of the periosteum has been found to be the determining factor in reducing postoperative pain and improving wound vascularization. Studies have reported encouraging data on the bone volume obtained for implant-prosthetic rehabilitation using this technique. (JOURNAL OF DENTAL IMPLANT RESEARCH 2021;40(2):48-53)
\end{abstract}

Key Words: Lateral ridge augmentation, Tunnel GBR, Lateral access bone regeneration, Tunnel technique bone augmentation

\section{INTRODUCTION}

In alveolar ridge deficit, guided bone regeneration (GBR) has been shown to be an effective technique for reestablishing adequate bone thickness ${ }^{1,2)}$. Traditionally, GBR techniques involve the elevation of a mucoperiosteal full-thickness flap to provide direct access to the bone defect. After debridement of soft tissue remnants from the bone defects, a bone graft is applied on the buccal aspect of the alveolar process, and a membrane is adapted and fixed to the graft and the surrounding bone. The incisions are then sutured with tension-free wound closure $^{3,4)}$. Regardless of the bone grafts and membranes used, these techniques use a periosteal incision to enable advancement of the mucoperiosteal flap. This incision has been associated with risks of complications, including wound dehiscence, membrane exposure, infection, swelling, and patient morbidity ${ }^{5}$.
Minimally invasive procedures with the tunnel technique have been suggested to decrease patient postoperative discomfort and morbidity. In the ridge augmentation tunnel technique, crestal incision and the release of the connective tissue are avoided in order to enhance the blood supply of the flap. This approach preserves the blood circulation and does not damage the periosteum ${ }^{6}$. Consequently, because the periosteum a source of progenitor and stem cells for tissue engineering ${ }^{7-12)}$, this method supports wound healing.

The tunnel technique further preserves peri-implant tissue by avoiding incision, thereby decreasing the possibility of scarring or esthetically undesirable defects on the soft tissue, which frequently occur with traditional bone regeneration procedures ${ }^{13)}$.

Tunnel GBR may be more operator- sensitive than conventional approaches and may also result in poor membrane stabilization and the dispersion of graft particles,

Received April 8, 2021, Revised May 8, 2021, Accepted May 11, 2021.

(c) Journal of Dental Implant Research.

This is an open access article distributed under the terms of the Creative Commons Attribution Non-Commercial License (http://creativecommons.org/licenses/by-nc/4.0) which permits unrestricted non-commercial use, distribution, and reproduction in any medium, provided the original work is properly cited.

Correspondence to: Giuseppe D'Albis, https://orcid.org/0000-0002-3577-3711

D'Albis Dental. Via Pietro Nenni 65, Mola di Bari (BA), 70042, Italy. Tel: +39 349510 3642, Fax: +39 080473 5236, E-mail: dalbisgiuseppe@hotmail.com

The authors thank Mrs. Fortunato Silvia, Mrs. Anna Cristino, Mrs. Anna Pace and Mrs. Sonia Conenna for their support and Dr. Micol Palma for her assistance in preparing this manuscript. 
thus preventing the desired results from being achieved $^{13-15)}$. Employing growth factors associated with biomaterials is an alternative method to avoid the use of membranes and lead to a desired outcome in tunnel approach bone regeneration ${ }^{16-18)}$.

This article examines the efficacy of the tunnel technique as an approach for ridge augmentation, including the materials and procedures, which can be applied to achieve prosthetic driven implant placement.

\section{MATERIAL AND METHODS}

The Medline and PubMed medical databases were searched for reports on tunnel access ridge augmentation published between 2005 and March 2021. The search strategy was limited to controlled clinical trials, prospective and retrospective studies, case series, case reports, and in vitro studies, published in English in dental journals. The following key words were used: lateral ridge augmentation, tunnel GBR, tunnel technique bone augmentation and lateral access bone augmentation. The electronic search was supplemented with a manual search of the following publications: International Journal of Oral and Maxillofacial Implants, The International Journal of Periodontics \& Restorative Dentistry, Implant Dentistry, Journal of Oral Implantology, Quintessence International, International Journal of Oral and
Maxillofacial Surgery and Clinical Oral Implants Research.

Articles were first screened according to their titles and abstracts and a full text reading of all selected articles was then conducted.

\section{RESULTS AND DISCUSSION}

The search strategy yielded 16 articles retrieved by electronic search and 4 articles retrieved by manual search. One duplicate article was excluded. Two articles were excluded because the studies did not properly treat the ridge augmentation in the tunnel approach but instead used an injection mode ${ }^{19,20)}$.

After the initial screening phase, 17 articles were eligible for full text reading and were selected for the review (Fig. 1).

The search protocol identified case reports, case series, and descriptive studies (Table 1$)^{21-37)}$.

The articles describe many surgical protocols. Fourteen articles describe lateral access from one vertical full-thickness incision in the mesial aspect of the bone defect from the free gingiva to the mucogingival junction $^{10-12,14-17,19,20,22-24,26)}$, two studies performed two vertical incisions, one mesial and one distal to the defect ${ }^{13,25)}$, and one study use three incisions, one vertical, one intrasulcular to the proximal teeth and one midcrestal to gain

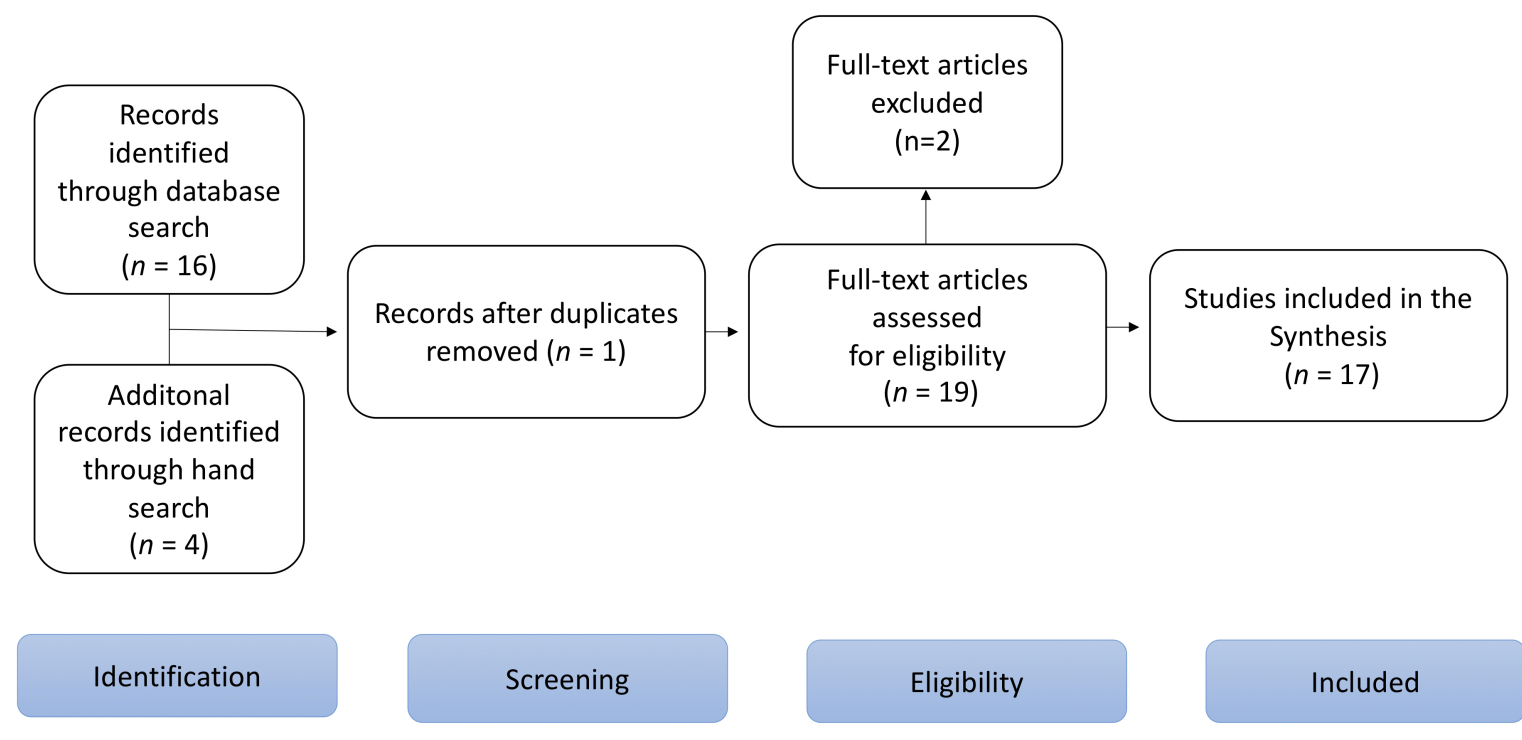

Fig. 1. Flow diagram of study inclusion. 
Table 1. Summary of the literature reviews

\begin{tabular}{|c|c|c|c|c|}
\hline Authors & Study design & Materials & Technique & Volume analysis procedures \\
\hline $\begin{array}{l}\text { Kfir E et al. } \\
2007^{21}\end{array}$ & $\begin{array}{l}\text { Descriptive }+ \text { Case } \\
\text { series }(n=11)\end{array}$ & $\begin{array}{l}\text { Biodegradable membrane, } \\
\text { autologous fibrin, synthetic bone. }\end{array}$ & $\begin{array}{l}1 \text { vertical incision/tunneling with } \\
\text { balloon/decortication/material } \\
\text { insertion }\end{array}$ & $\begin{array}{l}\text { - CT scan/panoramic and periapical } \\
\text { Rx before surgery and after } 5 \sim 6 \\
\text { month. }\end{array}$ \\
\hline $\begin{array}{l}\text { Hasson } 0 \text { et al. } \\
\text { 2007. }\end{array}$ & Case report $(n=7)$ & Bovine bone, collagen membrane. & $\begin{array}{l}1 \text { vertical incision/tunneling by } \\
\text { surgical instrument/decortication/ } \\
\text { material insertion }\end{array}$ & $\begin{array}{l}\text { - CT scan before and after } 4 \text { month } \\
\text { from surgery. }\end{array}$ \\
\hline $\begin{array}{l}\text { Kakar A et al. } \\
2018 .^{23}\end{array}$ & Case series $(n=9)$ & Synthetic bone. & $\begin{array}{l}1 \text { vertical incision/tunneling by } \\
\text { tunnel control instrument } \\
\text { set/decortication/material } \\
\text { insertion by syringe }\end{array}$ & $\begin{array}{l}\text { - СВCT before surgery and after } 4 \\
\text { month. } \\
\text { - Histological and histomorphometric } \\
\text { analysis. }\end{array}$ \\
\hline $\begin{array}{l}\text { Ponte A et al. } \\
2006 .^{24}\end{array}$ & $\begin{array}{l}\text { Descriptive+Case } \\
\text { report }\end{array}$ & Autologous block bone. & $\begin{array}{l}2 \text { vertical incision/block removed } \\
\text { from mandibular ramus and fitted } \\
\text { to defect }\end{array}$ & - Clinical and Rx valuation. \\
\hline $\begin{array}{l}\text { De Azevedo RA et } \\
\text { al. 2017. }\end{array}$ & Descriptive & Autologous bone. & $\begin{array}{l}1 \text { crestal incision/decortication/ } \\
\text { adapted the graft removed from } \\
\text { mandibular arch }\end{array}$ & $\begin{array}{l}\text { - CBCT valuation before and after } \\
\text { surgery }\end{array}$ \\
\hline $\begin{array}{l}\text { Kim HS et al. } \\
2016 . .^{26}\end{array}$ & $\begin{array}{l}\text { Retrospective study } \\
(\mathrm{n}=25)\end{array}$ & $\begin{array}{l}\text { Autogenous demineralized dentin } \\
\text { matrix/allograft/xenograft. }\end{array}$ & $\begin{array}{l}1 \text { vertical or horizontal } \\
\text { incision/tunneling by periosteal } \\
\text { elevator/bone graft placed }\end{array}$ & $\begin{array}{l}\text { - Panoramic and standardized } \\
\text { periapical radiographs pre- and } \\
\text { postoperatively } \\
\text { - } 1 \text { case evaluated with СBCT before } \\
\text { and after bone graft. }\end{array}$ \\
\hline Li J et al. $2013 .^{27}$ & $\begin{array}{l}\text { Prospective study } \\
\quad(n=9)\end{array}$ & Bovine bone block. & $\begin{array}{l}1 \text { vertical incision/tunneling by } \\
\text { periosteal elevator/stabilized } \\
\text { block bone }\end{array}$ & $\begin{array}{l}\text { - Clinical and Rx evaluation and } 6 \\
\text { month after surgery CBCT. } \\
\text { - Histological analysis. }\end{array}$ \\
\hline $\begin{array}{l}\text { Nevis ML et al. } \\
\text { 2009. }^{28}\end{array}$ & Case series $(n=12)$ & $\begin{array}{l}\text { rhPDGF-BB in combination with: } \\
\text { bone allograft, bovine bone, } \\
\text { mineralized collagen bone. }\end{array}$ & $\begin{array}{l}1 \text { vertical incision/tunneling by } \\
\text { periosteal elevator/decortication/ } \\
\text { graft insertion by syringe }\end{array}$ & $\begin{array}{l}\text { - Preoperative and post operative CT } \\
\text { scan. } \\
\text { - Micro CT and histomorphometry at } \\
14 \text { weeks. }\end{array}$ \\
\hline $\begin{array}{l}\text { Johnson TM et al. } \\
\text { 2018. }^{29}\end{array}$ & $\begin{array}{l}\text { Descriptive+Case } \\
\text { report }\end{array}$ & Bone allograft, dPTFE membrane. & $\begin{array}{l}3 \text { incision: } 1 \text { vertical, } 1 \text { infrasur- } \\
\text { cular of proximal teeth, } 1 \\
\text { midcrestal/tunneling by a surgery } \\
\text { kit/insertion of materials }\end{array}$ & $\begin{array}{l}\text { - СBCT before surgery. } \\
\text { - Clinical and Rx periapical control } \\
\text { after } 8 \text { month. }\end{array}$ \\
\hline $\begin{array}{l}\text { Block MS et al. } \\
2013 .^{30}\end{array}$ & $\begin{array}{l}\text { Descriptive+Case } \\
\text { report }\end{array}$ & $\begin{array}{l}\text { Collagen membrane, bovine } \\
\text { xenograft. }\end{array}$ & $\begin{array}{l}1 \text { vertical incision/tunneling by } \\
\text { periosteal elevator/material } \\
\text { insertion }\end{array}$ & $\begin{array}{l}\text { - CT scan after } 6 \text { month from } \\
\text { surgery. }\end{array}$ \\
\hline $\begin{array}{l}\text { De Stavola L and } \\
\text { Tunkel J. 2013. }{ }^{31}\end{array}$ & $\begin{array}{l}\text { Prospective study } \\
(\mathrm{n}=10)\end{array}$ & Autogenous bone block. & $\begin{array}{l}1 \text { vertical incision/tunneling by } \\
\text { surgical instrument/fixed bone } \\
\text { blocks and bone chips }\end{array}$ & - Radiograph pre e post-surgery. \\
\hline Lee EA $2017 .^{32}$ & $\begin{array}{l}\text { Prospective study } \\
\quad(n=21)\end{array}$ & $\begin{array}{l}\text { bovine bone mixed with } \\
\text { rhPDGF-BB. }\end{array}$ & $\begin{array}{l}\mathrm{n}^{\circ} \text { of incision depending of the } \\
\text { extension of the defect/tunneling } \\
\text { by surgical instrument/insertion } \\
\text { of graft }\end{array}$ & $\begin{array}{l}\text { - CBCT before surgery and after } \\
3 / 18 \text { month. } \\
\text { - Histology }\end{array}$ \\
\hline $\begin{array}{l}\text { Venet } L \text { et al. } \\
2017 .{ }^{33}\end{array}$ & Case series $(n=6)$ & Allograft block bone. & $\begin{array}{l}1 \text { vertical incision/tunneling by } \\
\text { periosteal elevator/piezo surgery } \\
\text { decortication/placed allograft } \\
\text { block }\end{array}$ & $\begin{array}{l}\text { - СВСТ pre operatory and } 6 \text { month } \\
\text { after surgery. }\end{array}$ \\
\hline $\begin{array}{l}\text { Karmon B et al. } \\
\text { 2019. }^{34}\end{array}$ & $\begin{array}{l}\text { Descriptive }+ \text { Case } \\
\text { series }(n=3)\end{array}$ & $\begin{array}{l}\text { Bovine xenograft, collagen } \\
\text { membrane. }\end{array}$ & $\begin{array}{l}1 \text { vertical incision/tunneling by } \\
\text { dedicate surgical set/insertion of } \\
\text { material bag }\end{array}$ & $\begin{array}{l}\text { - СВСT pre operatory and } 6 \text { month } \\
\text { after surgery. }\end{array}$ \\
\hline $\begin{array}{l}\text { Deeb GR et al. } \\
2016 .^{35}\end{array}$ & $\begin{array}{l}\text { Retrospective cohort } \\
\text { study }(n=21)\end{array}$ & $\begin{array}{l}\text { 1:1 allograft bone and xenograft } \\
\text { bone. }\end{array}$ & $\begin{array}{l}1 \text { vertical incision/tunneling by } \\
\text { periosteal elevator/graft insertion } \\
\text { by syringe }\end{array}$ & $\begin{array}{l}\text { - СBCT pre operatory and } 6 \text { month } \\
\text { after surgery. }\end{array}$ \\
\hline $\begin{array}{l}\text { Alghamdi } \mathrm{R} \text { et al. } \\
\text { 2020. }^{36}\end{array}$ & Case report & Allograft bone block & $\begin{array}{l}2 \text { vertical } \\
\text { incision/decortication/fixed bone } \\
\text { block }\end{array}$ & $\begin{array}{l}\text { - СВCT pre operatory and } 4 \text { month } \\
\text { after surgery. }\end{array}$ \\
\hline $\begin{array}{l}\text { Soltan } M \text { et al. } \\
2010 .^{37}\end{array}$ & Case report $(n=2)$ & $\begin{array}{l}\text { Hidroxiapatite or allograft+stem } \\
\text { cells }\end{array}$ & $\begin{array}{l}1 \text { incision/periosteal elevator is } \\
\text { used to dissect/graft insertion by } \\
\text { syringe }\end{array}$ & - Histology \\
\hline
\end{tabular}


access to the cortical bone and achieve correct membrane placement.

Use of surgical instruments and periosteal elevators for mucoperiosteal elevation of the flap was common among all the techniques. Kfir et al. additionally describe the use of a balloon inflated in the pocket to complete the tunneling.

Some authors describe decortication to harvest in-

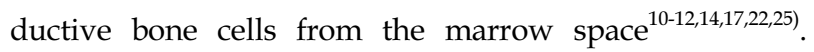
Venet et al. used piezo surgery for this passage.

The grafts inserted in the defects and the combinations of materials used were the most divergent aspects among the techniques described in the articles.

The application of a membrane as a structural support for the graft is described by five articles. A collagen membrane was used in association with autologous fibrin, synthetic bone ${ }^{10)}$, and bovine xenograft ${ }^{11,19,23)}$. The use of a dPTFE membrane is described by Johnson et al. in combination with allograft bone.

Five articles report the insertion of a bone block adaptation to the defect area and fixation with a titanium screw are described for a bovine bone block ${ }^{16)}$, allograft bone block ${ }^{22,25)}$, and autogenous bone block harvested from the external oblique ridge of the mandible ${ }^{13,20)}$.

Other authors report their experience in the insertion in the pocket of synthetic bone ${ }^{12}$, rhPDGF-BB in combination with bovine bone ${ }^{17,21)}$, allograft bone ${ }^{15,24,26)}$, xenograft bone ${ }^{15,24)}$, stem cells in combination with hidroxiapatite ${ }^{26)}$ and autologous bone removed from the mandibular $\operatorname{arch}^{14)}$.

To assess the volume, most authors of the identified articles, used two-dimensional measurements of the pre-intervention CBCT compared with those of the same segments after $4 / 6$ months.

Three studies provide evidence of the histological quality of the new tissue. The histological analysis by $\mathrm{Li}$ et al. showed that the xenograft particles were embedded in the woven bone 9 months after bone block insertion ${ }^{16)}$.

Moreover, histological analysis revealed new bone formation when rhPDGF-BB was used in combination with bone allograft, mineralized collagen bone ${ }^{17)}$, and bovine bone $^{21)}$.

The main advantage of the tunnel approach in bone regeneration is the ability to avoid the crestal incision while minimally compromising the blood supply in the flap and reducing damage and trauma to soft tissue ${ }^{13,26)}$.

This aspect is particularly important for patients with vascular problems, such as those who smoke, have diabetes and have scar tissue ${ }^{26)}$.

Lateral access facilitates the placement of a large amount of graft material through a small incision, and primary wound closure is easily accomplished ${ }^{10-26)}$.

Primary wound closure without tension on the suture line results in a lower risk of membrane exposure or need for antibiotic treatment than open-flap techniques ${ }^{24}$.

Suture line opening and early membrane exposure were not observed by any authors.

Decreased patient morbidity and discomfort are the most common factors reported in the clinical studies $^{10,13,19,21-26)}$.

To execute each technique, clinicians require adequate training. Furthermore, the use of appropriate instrumentation and biomaterials cannot be overemphasized.

Extreme caution must be exercised during the tunneling phase to avoid tissue perforation and to maintain the integrity of the periosteum. The absence of a direct view of the alveolar crest can be a limitation of the lateral approach in ridge augmentation.

Avoiding the use of membrane can make the procedure less invasive for patients and easier for the clinicians. One study has described the need to perform more incisions for the correct management of a dPTFE membrane ${ }^{18)}$.

The stability of the graft can be compromised thereby determining the final result. One study describes a patient who experienced bone resorption of the graft, owing to mobilization of a customized bone block ${ }^{22)}$.

Regardless of the bone grafts and membranes used, all studies except one achieved the prosthetic rehabilitation with implants. In one article, implant placement was not possible in two patients, owing to immature bone quality and limited bone volume, and three other implants did not achieve osseo-integration ${ }^{17)}$.

\section{CONCLUSION}

Alveolar ridge augmentation using subperiosteal tunneling is a minimally invasive procedure that provides 
access to the lateral ridge while preserving the integrity of the periosteum, thus decreasing postoperative discomfort, swelling, complications, and mobility.

Through this approach, regardless of the materials used, adequate bone volume is obtained for the insertion of implants.

However, further studies are necessary to determine the implant survival rate in tunnel ridge augmentation, because no long-term follow-up was performed in the analyzed articles.

\section{ORCID}

\author{
Giuseppe D'Albis, \\ https://orcid.org/0000-0002-3577-3711
}

\section{REFERENCES}

1. Benic $\mathrm{GI}$, Hämmerle $\mathrm{CH}$. Horizontal bone augmentation by means of guided bone regeneration. Periodontol 2000 2014;66:13-40.

2. Urban IA, Montero E, Monje A, Sanz- Sánchez I. Effectiveness of vertical ridge augmentation interventions: A systematic review and meta-analysis. J Clin Periodontol 2019;46(suppl 21):319-39.

3. Kim Y, Ku J. Ridge augmentation in implant dentistry. JKAOMS 2020;46:211-7

4. Kim Y, Ku J. Guided bone regeneration. JKAOMS 2020;46: 361-6.

5. Jensen AT, Jensen SS, Worsaae N. Complications related to bone augmen- tation procedures of localized defects in the alveolar ridge. A retrospective clini- cal study. Oral Maxillofac Surg 2016;20:115-22.

6. Mahn DH. Treatment of gingival recession with a modified "tunnel" technique and an acellular dermal connective tissue allograft. Pract Proced Aesthet Dent 2001;13:69-74.

7. Allen MR, Hock JM, Burr DB. Periosteum: biology, regulation, and response to osteoporosis therapies. Bone 2004;35: 1003-12.

8. Kanou M, Ueno T, Kagawa T, Fujii T, Sakata Y, Ishida N, et al. Osteogenic potential of primed periosteum graft in the rat calvarial model. Ann Plast Surg 2005;54:71-8.

9. Matsushima S, Isogai N, Jacquet R, Lowder E, Tokui T, Landis WJ. The nature and role of periosteum in bone and cartilage regeneration. Cells Tissues Organs 2011;194:320-5.

10. Zhu SJ, Choi BH, Huh JY, Jung JH, Kim BY, Lee SH. A comparative qualitative histological analysis of tissue-engineered bone using bone marrow mesenchymal stem cells, alveolar bone cells, and periosteal cells. Oral Surgery, Oral Medicine, Oral Pathology, Oral Radiology and Endodontology 2006;101: 164-9.
11. Roberts SJ, Geris L, Kerckhofs G, Desmet E, Schrooten J, Luyten FP. The combined bone forming capacity of human periosteal derived cells and calcium phosphates. Biomaterials 2011;32:4393-405.

12. Ceccarelli G, Graziano A, Benedetti L, Imbriani M, Romano F, Ferrarotti $F$, et al. Osteogenic potential of human oral-periosteal cells (PCs) isolated from different oral origin: an in vitro study. J Cell Physiol 2016;231:607-12.

13. Santing HJ, Raghoebar GM, Vissink A, den Hartog L, Meijer HJ. Performance of the Straumann bone level implant system for anterior single-tooth replacements in augmented and nonaugmented sites: A prospective cohort study with 60 consecutive patients. Clin Oral Implants Res 2013;24:941-8.

14. Zuhr O, Rebele SF, Cheung SL, Hürzeler MB, Research Group on Oral Soft Tis- sue Biology and Wound Healing. Surgery without papilla incision: Tunneling flap procedures in plastic periodontal and implant surgery. Periodontol 2000 2018;77: 123-49.

15. Cosyn J, Sabzevar M M, DeBruyn H. Predictors of interproximal and midfacial recession following single implant treatment in the anterior maxilla: A multi- variate analysis. J Clin Periodontol 2012; 39:895-903.

16. Simion M, Rocchietta I, Dellavia C. Three-dimensional ridge augmentation with xenograft and recombinant human platelet-derived growth factor-BB in humans: report of two cases. Int J Periodontics Restorative Dent 2007;27:109-15.

17. Rocchietta I, Dellavia C, Nevins M, Simion M. Bone regenerated via rhPDGF-bB and a deproteinized bovine bone matrix: backscattered electron microscopic element analysis. Int J Periodontics Restorative Dent 2007;27:539-45.

18. Fiorellini JP, Howell TH, Cochran D, Malmquist J, Lilly LC, Spagnoli D, et al. Randomized study evaluating recombinant human bone morphogenetic protein-2 for extraction socket augmentation. J Periodontol 2005;76:605-13.

19. Martínez-Sanz E, Varghese OP, Kisiel M, Engstrand T, Reich $\mathrm{KM}$, Bohner M, et al. Minimally invasive mandibular bone augmentation using injectable hydrogels. J Tissue Eng Regen Med 2012;6 Suppl 3:S15-23.

20. Hao J, Chou J, Kuroda S, Otsuka M, Kasugai S, Lang NP. Strontium hydroxyapatite in situ gel-forming system - a new approach for minimally invasive bone augmentation. Clin Oral Implants Res 2015;26:581-5.

21. Kfir E, Kfir V, Eliav E, Kaluski E. Minimally invasive guided bone regeneration. J Oral Implantol 2007;33:205-10.

22. Hasson 0. Augmentation of deficient lateral alveolar ridge using the subperiosteal tunneling dissection approach. Oral Surg Oral Med Oral Pathol Oral Radiol Endod 2007;103:e14-9.

23. Kakar A, Kakar K, Sripathi Rao BH, Lindner A, Nagursky H, Jain $\mathrm{G}$, et al. Lateral alveolar ridge augmentation procedure using subperiosteal tunneling technique: a pilot study. Maxillofac Plast Reconstr Surg 2018;40:3.

24. Ponte A, Happe A, Khoury F. The tunnel technique: Procedure for bone grafting before implant placement: a case study. Dentsply Friadent Identity 3:46-49, 2.

25. de Azevedo RA, Matos FS, Figueiredo LMG. Appositional bone graft tunneled: Technical note. Int J Surg Case Rep 2017; 
33:143-7.

26. Kim HS, Kim YK, Yun PY. Minimal invasive horizontal ridge augmentation using subperiosteal tunneling technique. Maxillofac Plast Reconstr Surg 2016;38:41.

27. Li J, Xuan F, Choi BH, Jeong SM. Minimally invasive ridge augmentation using xenogenous bone blocks in an atrophied posterior mandible: a clinical and histological study. Implant Dent 2013;22:112-6.

28. Nevins ML, Camelo M, Nevins M, Schupbach P, Friedland B, Camelo JM, et al. Minimally invasive alveolar ridge augmentation procedure (tunneling technique) using rhPDGF-BB in combination with three matrices: a case series. Int J Periodontics Restorative Dent 2009;29:371-83.

29. Johnson TM, Baron D. Tunnel access for guided bone regeneration in the maxillary anterior. Clinical Advances in Periodontics 2018;8:27-32.

30. Block MS, Kelley B. Horizontal posterior ridge augmentation: the use of a collagen membrane over a bovine particulate graft: technique note. J Oral Maxillofac Surg 2013;71:1513-9.

31. De Stavola L, Tunkel J. Results of vertical bone augmentation with autogenous bone block grafts and the tunnel technique: a clinical prospective study of 10 consecutively treated patients. Int J Periodontics Restorative Dent 2013;33:651-9.

32. Lee EA. Subperiosteal minimally invasive aesthetic ridge aug- mentation technique (SMART): a new standard for bone reconstruction of the jaws. Int J Periodontics Restorative Dent 2017;37:165-73.

33. Venet L, Perriat M, Mangano FG, Fortin T. Horizontal ridge reconstruction of the anterior maxilla using customized allogeneic bone blocks with a minimally invasive technique - a case series. BMC Oral Health 2017;17:146.

34. Karmon B, Tavelli L, Rasperini G. Tunnel technique with a subperiosteal bag for horizontal ridge augmentation. Int J Periodontics Restorative Dent 2020;40:223-30.

35. Deeb GR, Wilson GH, Carrico CK, Zafar U, Laskin DM, Deeb JG. Is the tunnel technique more effective than open augmentation with a titanium-reinforced polytetrafluoroethylene membrane for horizontal ridge augmentation? J Oral Maxillofac Surg 2016;74:1752-6.

36. Alghamdi R, Guei-hua GH, Sawada M, Kakumoto T, Cheng Yu PY, et al. Horizontal ridge augmentation using PDLLA fixing screw in combination with a block graft in a tunnel technique to replace amaxillary anterior missing tooth - a case report. J Oral Biol 2020;7:6.

37. Soltan M, Smiler D, Soltan C, Prasad HS, Rohrer MD. Bone grafting by means of a tunnel dissection: predictable results using stem cells and matrix. Implant Dent 2010;19:280-7. 